\title{
A LATE PLEISTOCENE/HOLOCENE BIOTIC COMMUNITY FROM MARMOT END ALCOVE, ESCALANTE RIVER BASIN, COLORADO PLATEAU, USA
}

\author{
Manny $\mathrm{Kropf}^{\mathrm{l}}$
}

\begin{abstract}
Skeletal remains of the extinct mountain goat Oreamnos harringtoni and Marmota (marmot), an extralimital species, were recovered from Marmot End Alcove along with remains of montane plants that included Pseudotsuga menziesii (Douglas-fir), Picea (spruce), Pinus flexilis (limber pine), and Juniperus communis (common juniper). The alcove is located in Harris Wash, a semiarid tributary in an unstudied portion of the Escalante River Basin on the Colorado Plateau in southern Utah. A Marmota incisor tooth and montane plant needles returned late Pleistocene AMS dates ranging from $12,300 \mathrm{yr} \mathrm{BP}$ to $15,600 \mathrm{yr} \mathrm{BP}$.
\end{abstract}

Key words: Marmota, Escalante River Basin, Colorado Plateau, Pleistocene, Harris Wash, Oreamnos harringtoni, Pseudotsuga menziesii, Picea, Pinus flexilis, Juniperus communis.

Marmot End Alcove is a small sandstone alcove located in Harris Wash, a tributary of the Escalante River situated in the heart of the Colorado Plateau. The site falls within the boundaries of the Glen Canyon National Recreation Area (GLCA; Fig. 1). Harris Wash drains an area of over $700 \mathrm{~km}^{2}$, from its inception at an elevation of $2800 \mathrm{~m}$ on the Kaiparowits Plateau to its union with the Escalante River at $1400 \mathrm{~m}$ (Patton and Boison 1986). From its confluence with the Escalante River to $16 \mathrm{~km}$ upstream, Harris Wash is a perennial stream with steepsided canyon walls. This stretch of the wash contains numerous alcoves that provide a unique, dry environment for the preservation of late Pleistocene remains.

Today, climate in the Harris Wash region is semiarid with seasonal rains and a mean annual temperature of $10-12{ }^{\circ} \mathrm{C}$. The landscape is dominated by an open pinyon-juniper woodland that includes desert scrub and sagebrush, while riparian vegetation with hanging gardens can be found along the stream bed (Withers and Mead 1993).

The elevation of the stream-level alluvial fill near the alcove is approximately $1460 \mathrm{~m}$, with the top of the canyon walls around 1525 $\mathrm{m}$ and the floor of the alcove approximately $25 \mathrm{~m}$ above stream level. The alcove entrance is 5.5 $\mathrm{m}$ high and $16.2 \mathrm{~m}$ wide. The floor of the alcove slopes up to the rear, a distance of 13.5 $\mathrm{m}$, to a small area of level sediment. The total area of the alcove floor, $220 \mathrm{~m}^{2}$, is covered with very loose sedimentary fill containing bone, plant material, and several large and small pieces of packrat midden. The packrat midden material appears to be falling from a ledge that runs along the ceiling of the alcove, but some of the material may be coming from below the floor fill.

The floor-fill deposits are fairly homogeneous in color and are typically sand-size with occasional rock slabs mixed in from episodes of roof fall. The majority of the sediments were probably deposited by in situ erosion of sandstone surfaces within the alcove, with some secondary deposition occurring from windblown sand. It is unlikely that stream elevation was once much higher than presently observed or that sediments were deposited into the alcove by the stream. Harris Wash has undergone several episodes of aggradation and degradation, but the highest alluvial terrace observed by Patton and Boison (1986) is not much higher than $10 \mathrm{~m}$, which falls short of the alcove floor elevation by $15 \mathrm{~m}$. The oldest date obtained by Patton and Boison (1986) for any alluvial terraces in the canyon is $8160 \mathrm{yr}$ BP. This may suggest that older deposits were removed by erosion before the end of the late Pleistocene. However, while hiking to the site, I noticed no evidence of alluvial terrace remnants that would suggest valley fills higher than the ones observed by Patton and Boison (1986).

\footnotetext{
${ }^{1}$ Laboratory of Quaternary Paleontology, Quaternary Sciences Program and Department of Geology, Northern Arizona University, Flagstaff, AZ 86011.
} E-mail: mannyandsusan@netzero.net 


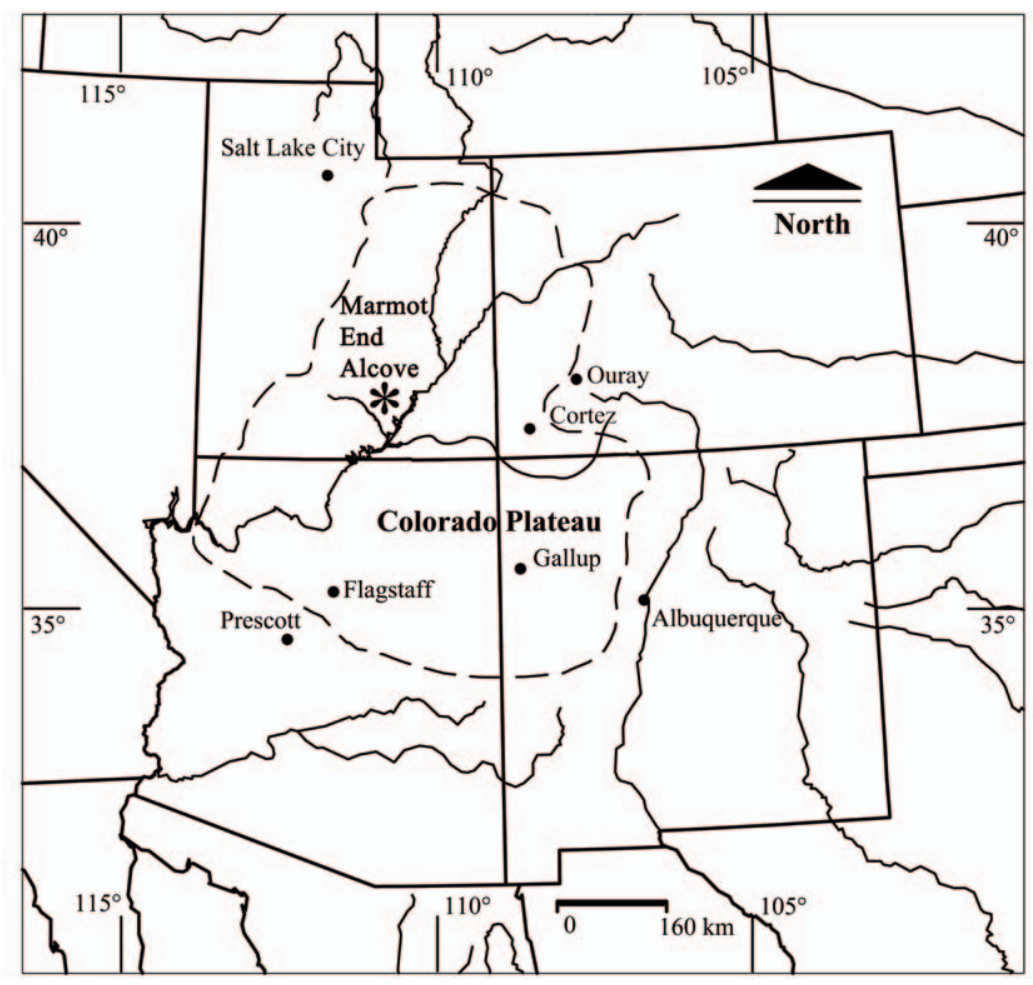

Fig. 1. Map of the Colorado Plateau illustrating the general location of Marmot End Alcove $\left.{ }^{*}\right)$.

Stratigraphy within the sedimentary floor fill was not evident in either a hole almost $30 \mathrm{~cm}$ deep near the north wall of the alcove or a test unit excavated to rock level. The lack of stratigraphy appears to be caused by several factors, such as constant reworking of the fill by wind action, human and animal foot traffic, rodent activity, and shallow depth of the deposits $(<1 \mathrm{~m})$. The reworking of the floor fill is possibly one reason why the recovered fauna is highly fragmentary, with new and old fossil remains intermixed. Without distinctive stratigraphic layering, chronological control for the collected materials is not possible. Radiocarbon dates were taken directly from a small sample of plant and skeletal remains (Table 1).

With permission from the National Park Service, all visible skeletal material at Marmot End Alcove was collected, along with floor sediment from a test unit and 3 masses of unattached packrat midden material from the floor. All collected material was brought back to the Laboratory of Quaternary Paleontology, Northern Arizona University, for cataloging, storage, and analysis.
The majority of fossil skeletal materials recovered from the alcove are mammal, with some material representative of lizards, snakes, birds, fish, and snails. For a more extensive treatment and discussion of the fauna and flora from the site, see Kropf (2005).

Many of the animal and plant taxa recovered from Marmot End Alcove still occur in the vicinity today; however, several do not, including Marmota, Oreamnos harringtoni (extinct Harrington's Mountain Goat), and plant material from Pseudotsuga menziesii, Picea, Pinus flexilis, and Juniperus communis. Modern Marmota populations on the Colorado Plateau are typically found only at elevations above $2000 \mathrm{~m}$, with the closest known Marmota population to Harris Wash occurring on the Aquarius Plateau approximately $50 \mathrm{~km}$ to the west (Frase and Hoffmann 1980).

Marmota skeletal material included most of a skull and right tibia, and fragments of a femur and 2 frontal bones. The skull (Fig. 2) and the fully preserved frontal bones indicate the skeletal presence of at least 3 individuals. The majority of the skull is intact, but it is missing a 
TABLE 1. Radiocarbon dates performed by the University of Arizona AMS laboratory for specimens from Marmot End Alcove, Harris Wash, Utah.

\begin{tabular}{lccl}
\hline $\begin{array}{l}\text { University of Arizona } \\
\text { sample number }\end{array}$ & $\begin{array}{c}\text { GLCA catalog } \\
\text { number }\end{array}$ & Date ${ }^{14} \mathrm{C}$ yr B.P. & \multicolumn{1}{c}{ Material dated } \\
\hline AA61376 & GLCA 22308 & Inadequate bone collagen & Oreamnos harringtoni metacarpal bone \\
AA61377 & GLCA 22252 & $12,880 \pm 110$ & Marmota cf. flaviventris - incisor tooth from skull \\
AA61377 & GLCA 22252 & $12,940 \pm 130$ & Marmota cf. flaviventris - incisor tooth from skull \\
AA61379 & GLCA 22329 & $12,302 \pm 70$ & Pinus flexilis needles from packrat mass \\
AA61380 & GLCA 22323 & $15,615 \pm 87$ & Picea sp. needles from floor sediment \\
\hline
\end{tabular}

portion of the premaxillary, all teeth except 3 , and most of the zygomatic arch. Skull length is $77 \mathrm{~mm}$ and width is $54 \mathrm{~mm}$. Tooth row length is $20.7 \mathrm{~mm}$. Palatal width at $\mathrm{P}^{3}$ is $15.8 \mathrm{~mm}$, and palatal width at $\mathrm{M}^{3}$ is $9.6 \mathrm{~mm}$. The material displayed characteristics typically found in the genus Marmota and not in similar size genera (i.e., Erethizon [porcupine], Castor [beaver], and Myocastor [nutria]): the distinctive flat shape of the skull, the brachyodont rooted teeth, the occlusal patterns to $\mathrm{LM}^{1}$ and $\mathrm{LM}^{3}$, the outline of the postorbital processes, and the large, squarish rostrum.

There are currently 6 North American species of Marmota. Marmota flaviventris is the most common and most widely distributed Marmota species in the western half of North America. In Montana and Washington, the range of $M$. flaviventris overlaps with the range of a second, closely related species, Marmota caligata (the hoary marmot), whose range extends to Alaska (Frase and Hoffmann 1980, Whitaker 1996). Studies by some researchers (Heaton 1985, Polly 2003, Schubert 2003) suggest species can be separated based on body size, size differences between $\mathrm{P}^{4}$ and $\mathrm{M}^{1}$, and molar shape; however, $\mathrm{P}^{4}$ is not available and body size is difficult to determine with the few fossil specimens available for analysis. I failed to find any significant differences in the molar shapes to suggest alignment with either M. caligata or M. flaviventris. The southern extent of M. caligata during the late Pleistocene is unknown, and its presence on the Colorado Plateau has not been previously reported. Until the late Pleistocene distribution of M. caligata is better understood and morphological differences are more clearly distinguished between species, I am tentatively assigning all the specimens to M. cf. flaviventris based on modern geographic distribution.

Oreamnos harringtoni skeletal material included a well-preserved adult right metacarpal and more fragmentary material: 2 right first phalanges, a left ulna, a left radius, a right innominate, and a right metacarpal. The complete right metacarpal measurements are total length $91 \mathrm{~mm}$, proximal width $30.8 \mathrm{~mm}$, proximal depth $19.1 \mathrm{~mm}$, distal width $32.7 \mathrm{~mm}$, and distal depth $19.3 \mathrm{~mm}$. Oreamnos harringtoni is an extinct species of mountain goat closely related to the living mountain goat, Oreamnos americanus. The remains of $O$. harringtoni have been found in more than a dozen localities throughout the Southwest, with the greatest concentration of remains coming from the Grand Canyon (Mead et al. 1987, Mead and Lawler 1994).

Table 2 lists the plant material identified from a packrat midden mass consisting of 14 genera, 8 of which were identified to species level. No identifiable skeletal material was recovered from the midden mass. Table 3 lists the plant material identified from the sedimentary floor unit, consisting of 32 genera, 8 of which were identified to species level. This variety of plants represents the diverse topography near Marmot End Alcove, which consists of dry slickrock terraces, sand dunes, a perennial stream, and microenvironments created by the varying slopes and orientations of the canyon walls.

Pseudotsuga menziesii, Picea, Pinus flexilis, and Juniperus communis do not occur in Harris Wash, in protected microenvironments, or above the canyon walls. Much of the region today, from stream level to an elevation of $2300 \mathrm{~m}$, is dominated by a pinyon-juniper woodland (Withers and Mead 1993). Many of the elevationally depressed montane species mentioned above occur today only in the higher elevations of the Aquarius Plateau and the Henry Mountains, located $50 \mathrm{~km}$ to the north and northwest, respectively (Dixon 1935, Spaulding and Van Devender 1977, Welsh et al. 1978, Betancourt 1984, Withers and Mead 1993). Picea populations typically occur at elevations ranging from 3660 to $2438 \mathrm{~m}$, although some Picea 


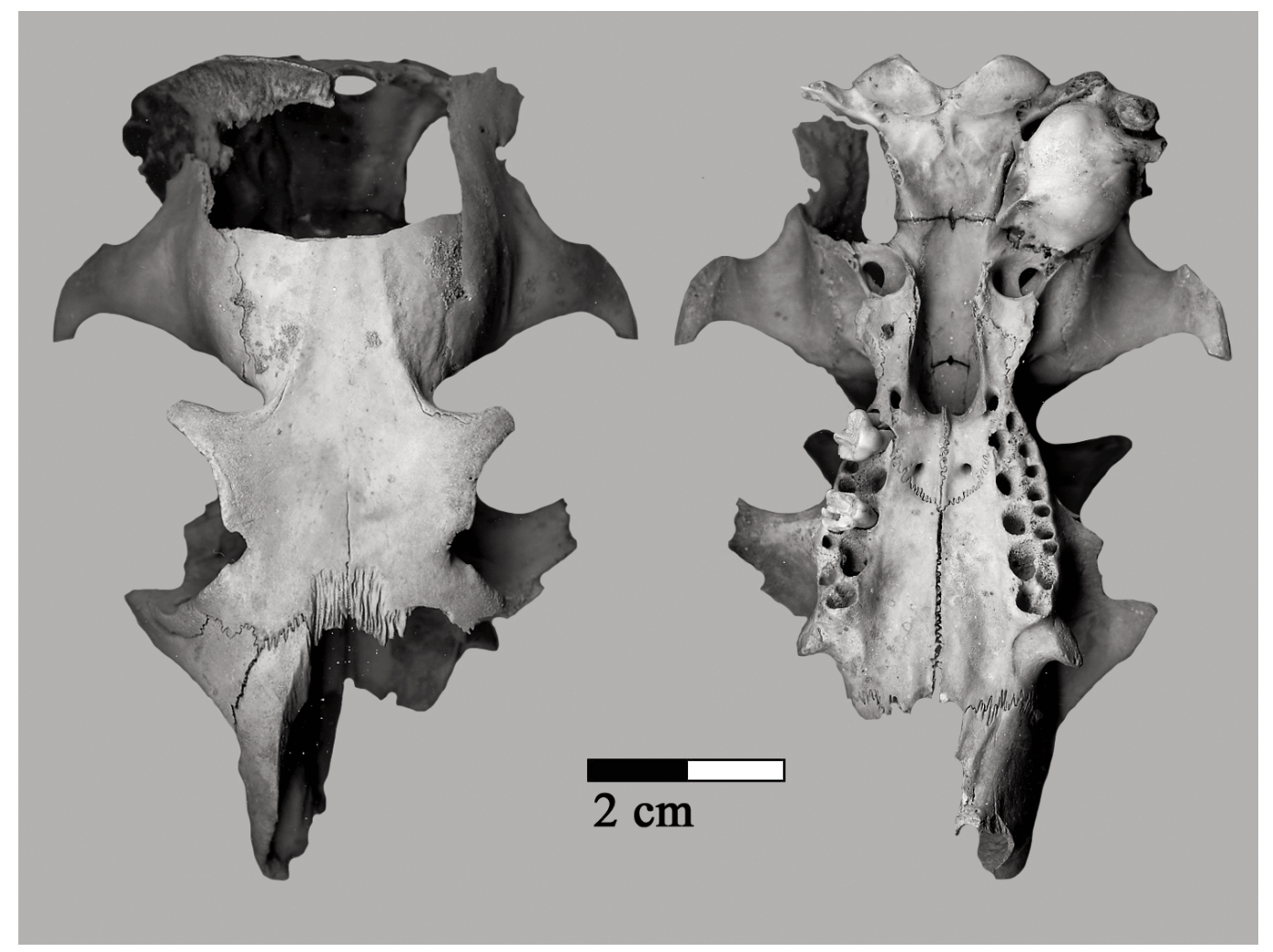

Fig. 2. Dorsal and ventral view of fossil Marmota skull GLCA 22252.

populations in the Henry Mountains occur at elevations as low as $2140 \mathrm{~m}$ (Spaulding and Van Devender 1977). Pseudotsuga menziesii trees typically occur in mixed-conifer forests at elevations ranging from 3048 to $2438 \mathrm{~m}$; however, some relict populations of $P$. menziesii occur in canyons at elevations as low as $1830 \mathrm{~m}$ (Spaulding and Van Devender 1977, Betancourt 1984). Pinus flexilis typically occurs near the uppermost tree zone with Picea populations, but it is apparently not a common tree in the higher elevations of southern Utah today and is absent from some of the smaller nearby mountain ranges (Welsh et al. 1978, Betancourt 1984).

Several localities in or near the Escalante River Basin contain sites where paleoenvironmental research has focused on pre-Quaternary deposits and their plant remains. Picea and Pseudotsuga menziesii macrobotanical remains were recovered by Withers and Mead (1993) from alcove deposits in Forty Mile Canyon. The canyon is located $40 \mathrm{~km}$ south of Harris Wash at an elevation of $1200 \mathrm{~m}$. Picea twigs were found below a layer dating to $11,690 \mathrm{yr}$ BP, while Pseudotsuga menziesii needles were dated directly to $12,130 \mathrm{yr}$ BP. At an elevation of $1710 \mathrm{~m}$ in Cowboy Cave in southern Utah, Picea and Pseudotsuga needles were found mixed within a dung layer dating to $11,810 \mathrm{yr}$ BP (Spaulding and Van Devender 1977). Plant macrofossils from packrat middens in 2 southeastern caves, Fishmouth Cave and Allen Canyon Cave (elevations of $1585 \mathrm{~m}$ and $2195 \mathrm{~m}$, respectively) were analyzed and radiocarbon dated by Betancourt (1984). Pseudotsuga menziesii, Picea, Pinus flexilis, and Juniperus communis were common at both sites before $9380 \mathrm{yr}$ BP. The results suggest that during the early Holocene, the montane species of the late Pleistocene were displaced by 700 to $800 \mathrm{~m}$ in elevation, as suggested by Cole (1990) and Betancourt (1984). Marmot End Alcove, at $1485 \mathrm{~m}$, appears to have experienced a similar shift in elevation of plant communities during the early Holocene.

In summary, the discovery of late Pleistocene fossil remains at Marmot End Alcove has provided additional knowledge of the fauna and 
TABLE 2. List of all plant material identified from a packrat midden mass taken from Marmot End Alcove, Harris Wash, Utah. Asterisks indicate extralimital species.

\begin{tabular}{lll}
\hline Plants & Common name & Plant material \\
\hline Cercocarpus & mountain mahogany & leaves \\
Corispermum & American bugseed & seeds \\
Ephedra & Mormon tea & seeds \\
*Juniperus communis & common juniper & leaves \\
Juniperus osteosperma & Utah juniper & twig fragments \\
Juniperus scopulorum & Rocky Mountain juniper & twig fragments \\
Lithospermum multiflorum & Gromwell/puccoon & seeds \\
Opuntia & pricklypear & seeds, spines and glochids \\
Achnatherum hymenoides & Indian ricegrass & seeds \\
*Picea & spruce & needles \\
$*$ *inus flexilis & limber pine & needles \\
$*$ Pseudotsuga menziesii & Douglas-fir & needles \\
Quercus & oak & acorn fragments \\
Rhus trilobata & skunkbush sumac & seeds \\
Rosa & wild rose & seeds \\
Yucca & yucca & seeds and leaf tips \\
\hline
\end{tabular}

TABLE 3. List of all plant material identified from the test unit sediments, Marmot End Alcove, Harris Wash, Utah. Asterisks indicate extralimital species.

\begin{tabular}{|c|c|c|}
\hline Plants & Common name & Plant material \\
\hline Acer negundo & boxelder & seeds \\
\hline Agave & agave & seeds \\
\hline Arabis & rockcress & leaves \\
\hline Artemisia & sagebrush & leaves \\
\hline Astragalus & milkvetch & seeds \\
\hline Atriplex & saltbush & seed fragments \\
\hline Berberis & barberry & seeds \\
\hline Celtis & hackberry & seeds \\
\hline Cercocarpus & mountain mahogany & leaves \\
\hline Corispermum & American bugseed & seeds \\
\hline Ephedra & Mormon tea & seed and twig fragments \\
\hline Equisetum & horsetail & twig fragments \\
\hline Festuca & fescue & seeds \\
\hline Fraxinus anomala & singleleaf ash & seed and twig fragments \\
\hline Hesperostipa & needle and thread & seeds \\
\hline *Juniperus communis & common juniper & leaves \\
\hline Juniperus monosperma & oneseed juniper & twig fragments \\
\hline Juniperus osteosperma & Utah juniper & twig fragments \\
\hline Lithospermum multiflorum & Gromwell/puccoon & seeds \\
\hline Mirabilis & four o'clock & seeds \\
\hline Opuntia & pricklypear & seeds, spines and glochids \\
\hline Achnatherum hymenoides & Indian ricegrass & seeds \\
\hline *Picea & spruce & needles \\
\hline Pinus edulis & twoneedle pinyon & needles \\
\hline *Pinus flexilis & limber pine & needles \\
\hline *Pseudotsuga menziesii & Douglas-fir & needles \\
\hline Quercus & oak & acorn fragments \\
\hline Rhus trilobata & skunkbush sumac & seeds \\
\hline Rosa & wild rose & seeds \\
\hline Rosaceae & cliffrose / Apache plume & leaves \\
\hline Sclerocactus/Echinocereus & hedgehog cactus & seeds \\
\hline Shepherdia & buffaloberry & seeds \\
\hline Sphaeralcea & globemallow & seeds \\
\hline Sporobolus cryptandus & sand dropseed & panicle with seeds \\
\hline Yucca & yucca & leaf tips \\
\hline Zea mays & corn & seed kernels \\
\hline
\end{tabular}


flora of the Colorado Plateau from a new locality in an unstudied portion of the Escalante River Basin. The discovery of Marmota (marmot) remains introduces a new taxon previously unreported for the Escalante River Basin, and skeletal remains of Oreamnos harringtoni (extinct mountain goat; dung and skeletal remains have previously been identified from the region) provide supplementary evidence for its occurrence in the Escalante River Basin. In addition, the site demonstrates once again that a dramatic late Pleistocene climate shift caused a major reorganization of plant and animal communities on the Colorado Plateau, with the local extinction of mountain goats and marmots, the northward and upward migration of montane plant species, and the continued presence and arrival of southern plant species adapted to lower elevations.

Thanks to John Ritenour, Chief of Resource Management at Glen Canyon National Recreation Area, for allowing me to conduct scientific research and to collect at Marmot End Alcove. Thanks to Chris Goetze, Norm Henderson, John Spence, and Chris Kincaid for their assistance and support during my research there. A very sincere thanks to Dr. Paul S. Martin, the AMS facility at the University of Arizona, and the National Science Foundation for their help in obtaining radiocarbon dates. Thanks also to Sandy Swift, Quaternary Studies Collections Manager at Northern Arizona University, for providing help in the lab and photographing marmot skulls; to Susan Hall, my wife, for editorial assistance; and to Jim Mead.

\section{Literature Cited}

BETANCOURT, J.L. 1984. Late Quaternary plant zonation and climate in southeastern Utah. Great Basin Naturalist $44: 1-35$.

Cole, K.L. 1990. Late Quaternary vegetation gradients through the Grand Canyon. Pages 240-258 in J.L.
Betancourt, T.R. Van Devender, and P.S. Martin, editors, Packrat middens: the last 40,000 years of biotic change. University of Arizona Press, Tucson, AZ.

Dixon, H. 1935. Ecological studies on the high plateaus of Utah. Botanical Gazette 97:272-320.

Frase, B.A., and R.S. Hoffmann. 1980. Marmota flaviventris. Mammalian Species 135:1-8.

HEATON, T.H. 1985. Quaternary paleontology and paleoecology of Crystal Ball Cave, Millard County, Utah: with emphasis on mammals and descriptions of a new species of fossil skunk. Great Basin Naturalist 45: 337-390.

Kворғ, M. 2005. The extinct shrub-ox (Euceratherium collinum) and its late Quaternary environment on the Colorado Plateau. Master's thesis, Northern Arizona University, Flagstaff, AZ. 179 pp.

Mead, J.I., L.D. AgenBroad, A.M. Phillips, AND L.T. MidDLETON. 1987. Extinct mountain goat (Oreamnos harringtoni) in southeastern Utah. Quaternary Research 27:323-331.

MEAD, J.I., AND M.C. LAWLER. 1994. Skull, mandible, and metapodials of the extinct Harrington's mountain goat (Oreamnos harringtoni). Journal of Vertebrate Paleontology 14:562-576.

PatTon, P.C., AND P.J. BoISON. 1986. Processes and rates of formation of Holocene alluvial terraces in Harris Wash, Escalante River basin, south-central Utah. Geological Society of America Bulletin 97:369-378.

PoLLY, P.D. 2003. Paleophylogeography: the tempo of geographic differentiation in marmots (Marmota). Journal of Mammalogy 84:369-384.

SCHUBERT, B.W. 2003. A late Pleistocene and early Holocene mammalian fauna from Little Beaver Cave, Central Ozarks, Missouri. Pages 262-272 in B.W. Schubert, J.I. Mead, and R.W. Graham, editors, Ice Age cave faunas of North America. Indiana University Press, Bloomington and Indianapolis, IN.

Spaulding, W.G., and T.R. Van Devender. 1977. Late Pleistocene montane conifers in southeastern Utah. Southwestern Naturalist 22:269-270.

Welsh, S.L., N.D. ATwood, AND J.R. Murdock. 1978. Kaiparowits flora. Great Basin Naturalist 38:125-179.

WhitAKer, J.O. 1996. National Audubon Society field guide to North American mammals. Alfred A. Knopf Inc., New York, NY. 937 pp.

WithERS, K., AND J.I. MEAD. 1993. Late Quaternary vegetation and climate in the Escalante River basin on the central Colorado Plateau. Great Basin Naturalist 53: 145-161.

Received 31 July 2009 Accepted 14 April 2010 